\title{
溢光照明設計法に就いて
}

\author{
正會具大山松次郎 \\ 池田金 三
}

（束京帝國大學工學 部）

\section{Some Notes on Designing Method of Floodlighting.}

By M. Oyama, Member and K. Ikeda.

(Tokyo Imperial University)

梗概

投光器よりの光杜を任意你度で照明面に當てな時

合，均等度を調べる便法を紹介して居る。

の照度分布圆を求め，數個の光杜を重ねて用ひる場

\section{Synopsis.}

Illumination by floodlighting projector is graphically analyzed, and iso-lux curves of illuminated plane is obtained by our graphical method. When wide area is illuminated by many projectors, beams

\section{1. 緒害}

著者等は，溢光照明に就いて平素特に研究をして居る者でないから，以下述へるてとは或は陳 炭な事であるか子知れぬ。先頃ある目的で，後述の例にあるやうな溢光照明の設計をする必要が あつて，少（照明の書物を調べて見たが，丁度吾くの場合に適當と思はれる方法が見當らなかつ た。そてで我流の方法を案出して間に合せた。今て」に其の方法を發表して會員諸君の御批制や 御改良を仰ぐ次第である。

\section{2. 一投光器に依る投射面の照度}

投光器より出る光は，ある角度を張る光柱で，照明空間は多く圓錐狀になつてるる。中には四 角な投光器で角錐に近いるのもある。

從つて任意の方向の平面を照らすと，前者では棈圓形に，後者では梯形に，明るい處が出る。 Sylvester-Ritchie $\sigma^{*}$ 書物には，乙の圆錐の場合を取扱ひ，光柱の發散角 $8^{\circ}, 10^{\circ}, 12^{\circ}, 16^{\circ}$, $18^{\circ}, 20^{\circ}, 22^{\circ}, 44^{\circ}, 50^{\circ}, 60^{\circ}$,のものに付を, 光桂軸と，直棦， $75^{\circ}, 60^{\circ}, 45^{\circ}, 30^{\circ}$ ，をなす照 明面の棈圆の大きさを計算して表示してある。

然し䔈際設計する時には，上記の楕圆の大さ丈りでは足らない。何となれば，照明面に出來た 譛圆形內は等照度ではない。從つてその圖形內に等照度の軌践を知らねばならぬ。

先づ投光器より，發する光柱が余り細くなく照明面との距離も相虽あるとする。つをり光杜は 投光器の位置を點光源の位置とし, 光は逆二乘の法則に從ふものとして計算し誤差の少ない場合

* Cyril Sylvester and Thomas E. Ritchie :- Modern Electrical Illumination, 1927. 
とする。

先づ第一圖に於いて光杜を $O$ 點を通る直角面 $C O C^{\prime}$ で截り，その光柱の形を圖上に示す。

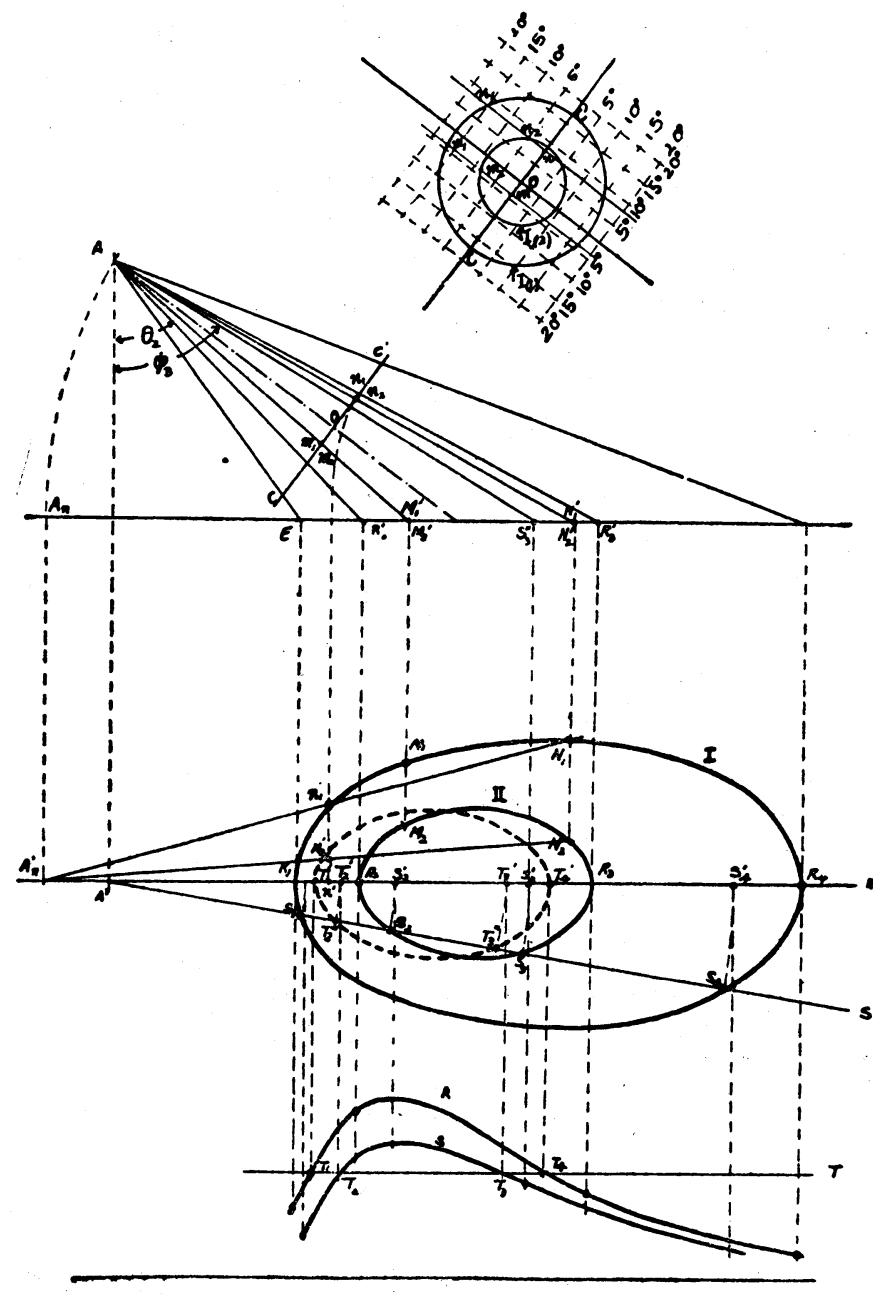

第 一 圆

投光器慗造者は，光柱の配光曲線を提示ナるが，それは光源よりある距離(侧へば 100 尺)へだ てた點で，测定し光柱軸となす角度と皮相燭光を圖示するものである。例へば第二圖はその一例 であるが，てれより，光柱截斷面に，らつし取り（截斷面では角度目盛が均一ならさるに依り， 等燭曲線は，角度目盛を，たどつて，プロットし直す。但し第二圖のやらな不規則な形をそのま \プロットナるには及ばぬ。各器具にも依り，又電球の取り换へ等で多少變形ナるるのであるか ら，便宜，對稱的な曲線に，ならしてプロットすればよん）。今設明のため，圖の複雜を避けて， 等燭曲線を二つ丈けに止める。次にての等燭曲線に相等する部分の光が照明面に畫く形を作虽で 求める。郎ち $n_{1}, n_{2}$ を通過する光が，照明面上 $N_{1}, N_{2}$ に到達するてとを見るには，A $N_{1} N_{2}$ 面を $N_{1}, N_{2}$ を軸として照明面に倒す。 $A$ は $A_{n}$ になり, 


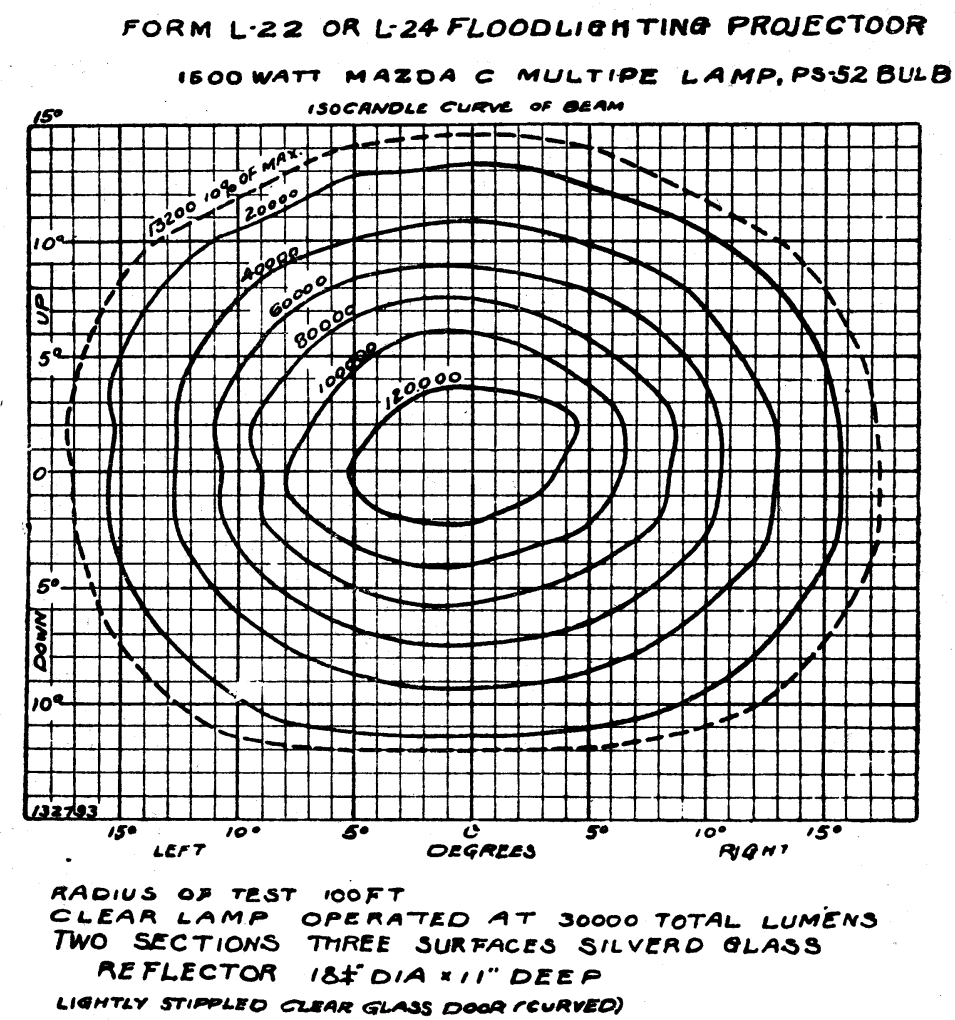

$$
\begin{aligned}
& \text { 第 二 圖 } \\
& A_{n}{ }^{\prime}-n^{\prime} \text { を } A-n \text { に等しく取り } \\
& n^{\prime} n_{1}{ }^{\prime} \text { を } n n_{1} \quad " \quad " A_{n}{ }^{\prime} n_{1}{ }^{\prime} \text { をつな元，長して } N_{1} \text { を求め } \\
& n^{\prime} n_{2}^{\prime} n_{2} \quad " \quad A_{22} n_{2}^{\prime} " \| " N_{2} "
\end{aligned}
$$

同橉のととを $m_{1}, m_{2}, \boldsymbol{M}_{1}, \boldsymbol{M}_{2}$ 等につんて行へば等燭光線の照明面に突當る曲線 $(\boldsymbol{I}$ 並に $I I)$; が求められる。

第三に照明面の照度を求める。便宜上， $A^{\prime}-R, A^{\prime}-S$ に沿つて求める。例へば $A^{\prime} R$ では $R_{1}$ $R_{2} R_{3} \quad R_{1}$ 點で求める。 $R_{2}$ に付いて說明すれば，

作圖に依り $R_{2}$ より $R_{2}^{\prime}$ を得， $\theta_{2}$ を得。

$$
\frac{l_{(2)}}{h^{2}} \cos ^{3} \theta_{2}
$$

を以て $R_{2}$ の照度とする。

同樣にして $R_{1} R_{3} R_{4}$ 等の照度を求め, 下圖に照度曲線 $R$ を作る。

刃 $A^{\prime} S$ では, $S_{1} S_{2} S_{3} S_{4}$ てつ求める。それには $A^{\prime}$ を中心として $A^{\prime} S$ を， $A^{\prime} R$ の方 向飞迴轉し，例人ば $S_{3}{ }^{\prime}$ を得 $S_{3}{ }^{\prime \prime}$ を得， $\phi_{3}$ を得。

$$
\frac{I_{(2)}}{h^{2}} \cos ^{3} \phi_{3}
$$


を $S_{3}$ の照庇とする。之より照度曲線 $S$ を作る。

第四に等照度曲線を畫く，それには $A^{\prime} R ， A^{\prime} S \ldots \ldots .$. の線上に等梁度點を見出して，つなぐ方針 で，照度曲線を適宜の照度線で切る。

例へば $T$ 照度に相當する點を照明面に求めるには, $T_{1} T_{4}$ は直ちに $T_{1}^{\prime}, T_{4}{ }^{\prime} ; T_{2}, T_{3}$ は $T_{2}$ $T_{3}{ }^{\prime}$ より $A S$ 几杘して $T_{2}{ }^{\prime \prime}, T_{3}{ }^{\prime \prime}$ を得る。てれから $T_{1}{ }^{\prime}, T_{2}{ }^{\prime \prime}, T_{3}{ }^{\prime \prime}, T_{4}{ }^{\prime}$ 等を結んで等照度曲線か 得られる。第三圖はかくして求めた等照度曲線圖である。

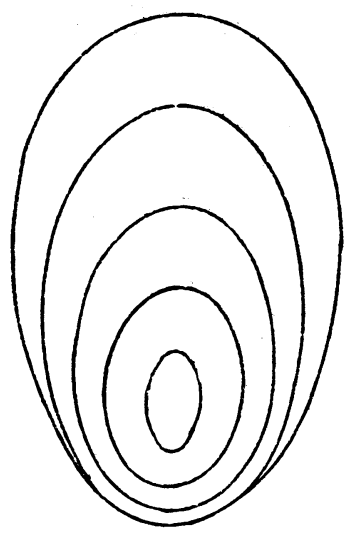

第 三 圖

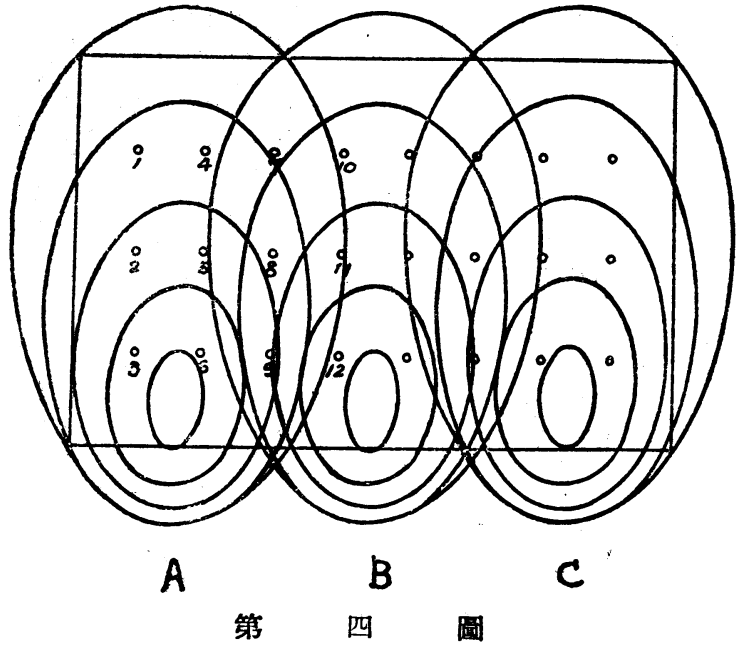

第 四 圆

\section{3. 數個の投光器を併用する時}

照明面を數個の投光器に俵り照明する場合は，光柱を重ね合するととになる。（第四圖は短形 照明面を三個つ光柱で照らしてるる圖である）その結果照明面の照度が均齊なるやらする事は， 良レェフェクトを得るに重要なてとである。

それイは，第三圖に得た圖をトレーシング・ベーパーか何かに書いて，照明面の上に載せ，照 明面上の任意の點を透し見て，其の照度を讀み取る。7，8．... 等の點は光柱二つが重なり合ふ所 であるから、トレーシング・ペーパーの等照度圖を $A$ 亿置いたときの讀みと， $B$ 亿置時の讀 みを加へる必要がある。斯くの如くして，各點の照度を詳細に記入し等照度の點をつないで，等 照度曲線が得られる。この方法は重なり合ひの數が多くなると，加算が面倒である。

そてで吾くは次の方法を試みた。それは，等照度圖に相當した紙（トレーシング・ペーパーヌ はパラフィン紙）を切り重ね合す。郎ち 0.25 呎燭以上の面積の所は一枚, 0.5 呎燭以上の所は更 らに一枚と云ふ風に重ねる。郎ち第三圖の形の，八重紧きの花辨見たいなるのが出來上る。羄山 重つた所が照度が高い。之を照明面（トレーシング・ペーパー）の上に载せて透かして見れば均 等度は一目瞭然である。記錄するには, 青寫訔に燒くとよん。照度の高い所程白く出る。從つて 多くの投光器を用ひ光挂を重ねる時は，乙の花辨型の照度紙型を，その數文け準借して，照明面 に重ね，透視して均等度と調整し，適當の位置にセツトして，投光器の位置を決定すればよい。 又記錄するには青寫具にでもとれば益々妙であらら。第五踖参照。 


\section{4. 钤你例}

近時スボーツの隆盛は，まことに素啨らしいものである。神宫外苑の競技場や野球場は，その シーズンになると大變な雜踏を極めるのである。すう二つ位外苑程度の設㑷が必要に見られる。 そてで，夕方から夜間へかけての使用を㨅へる必要がある。吾々はその計畫に資するためのデー ターを作る目的で，先つ゚競技場に應用して兄た。（第六圖參照）

第七圖はフィールドやフットボールの時。

第八圖はトラック使用の時の照明である。

前述の方法に依つたのである。第八圖の方は No. 3 及び No. 4 亿各 3 個の投光器を餘計に點 オる丈けでする。コーナー,スタートの處をよくしたものである。設計の詳細なデーターは本題 から脫線するととになるから上記の圖面を揚げるに留める。

\section{5. 適 要}

上述のてとを的言すれば，投光器よりの光社を，任意角度の照明面に當てた時，如何なる照度 分布になるかを，作圖法で决定し，且つ數多の投光器を使用する時の照度均等度を見る簡便法を 逨べたりのである。

附記 東京電氣株式會社の太田二郎氏からは，實際の投光器につんて御教示を得, 又花田助 手に圖面の調製を煩はしたてとをてっに深く感謝の意を表する。 


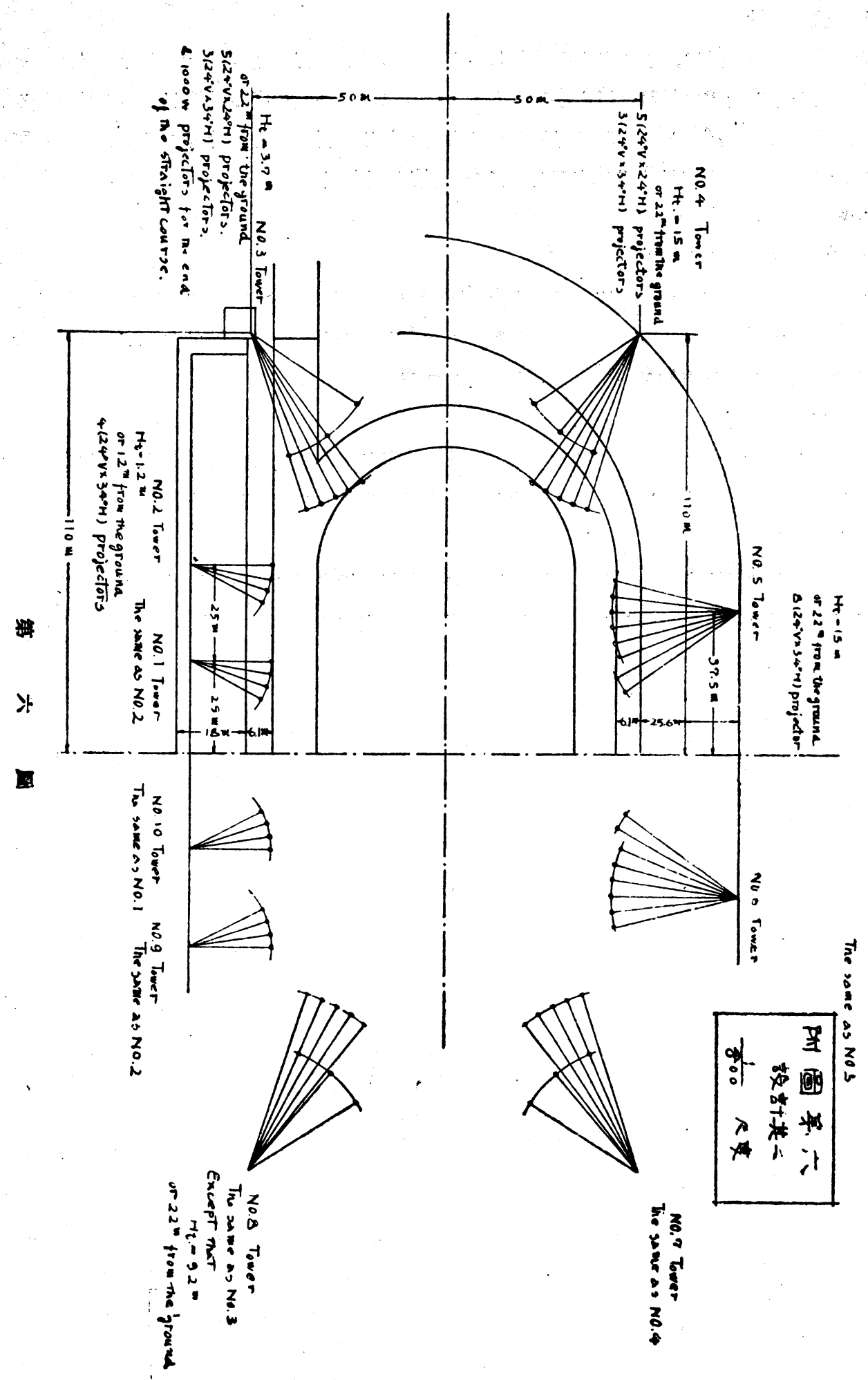




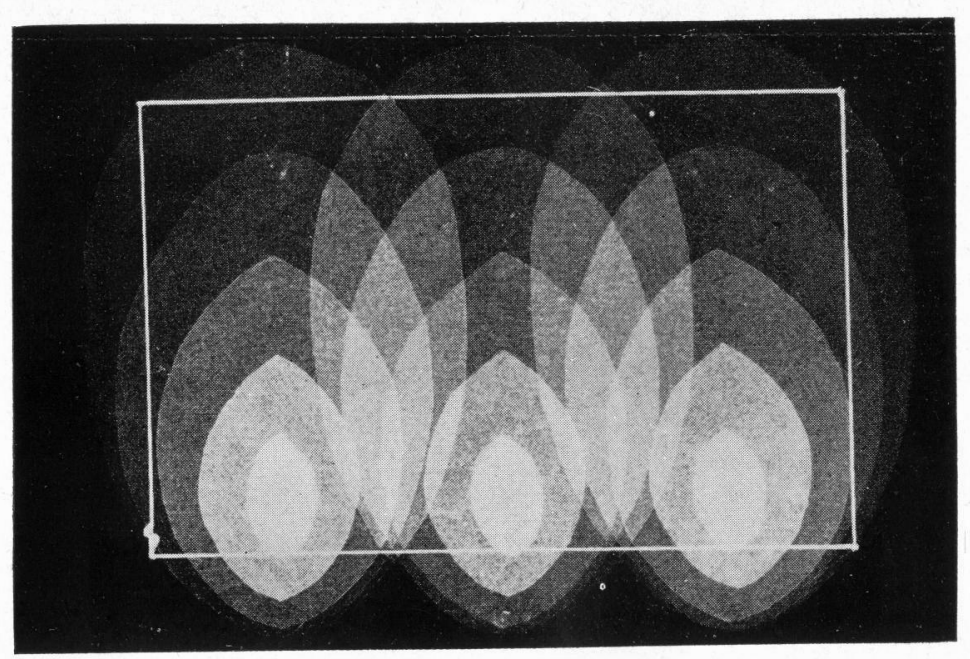

第五圖

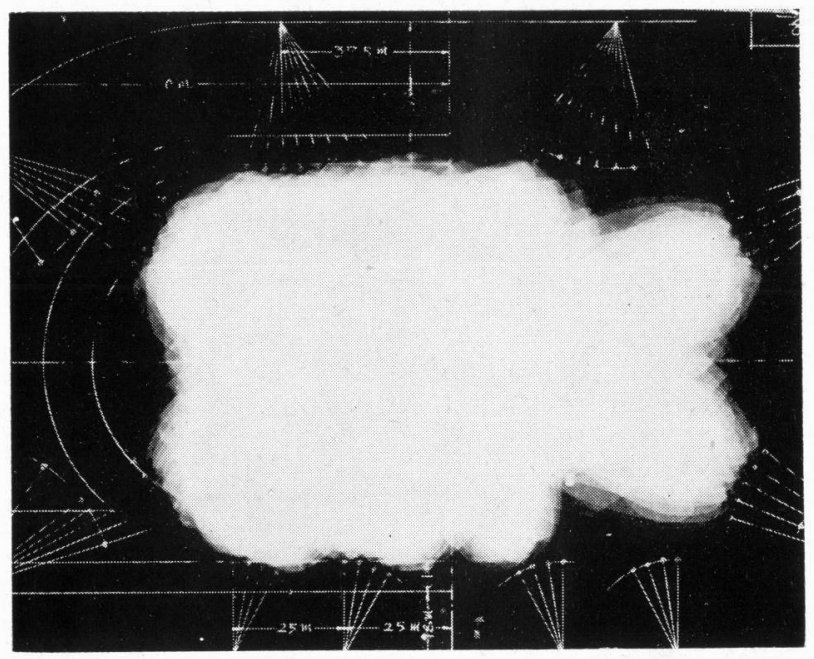

第 七 圖

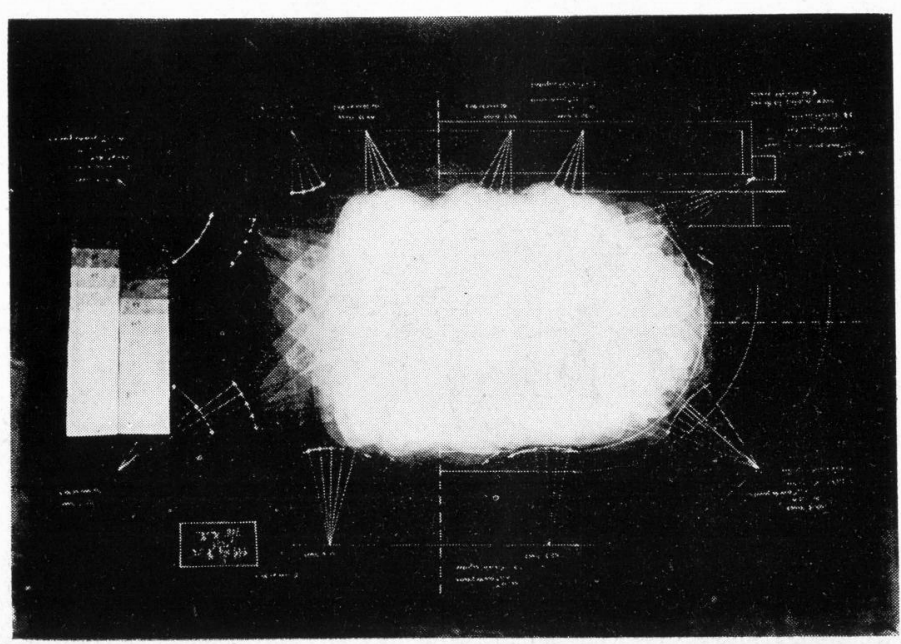

籍分回 